O eixo e a roda, Belo Horizonte, v.25, n.2, p. 47-64, 2016

\title{
No trivial da ideia: o rural e o urbano no conto brasileiro na Primeira República
}

\section{The rural and the urban in Brazilian short stories during the First Republic}

Luís Bueno

Universidade Federal do Paraná (UFPR), Curitiba / Brasil luis@ufpr.br

Resumo: Por meio da análise de dois contos, "Banzo" (1913), de Coelho Neto, e "A Favela que eu vi" (1924), de Benjamim Costallat, este trabalho propõe uma discussão a respeito de um conceito corrente e fundamental na historiografia literária brasileira: o regionalismo. O objetivo é estabelecer que a literatura rural nem sempre está assim tão distante da urbana. Procura-se demonstrar que o problema central de representação literária do regionalismo, ou seja, a distância que existe entre o narrador urbano, letrado, e os personagens rurais, iletrados, também se manifesta claramente entre aquele narrador e os personagens pobres radicados em ambientes urbanos marginais.

Palavras-chave: regionalismo; conto brasileiro; Coelho Neto; Benjamim Costallat.

Abstract: By means of an analysis of two short stories, namely Coelho Neto's "Banzo" (1913) and Benjamim Costallat's "A Favela que eu vi" (1924), this paper suggests that it is possible to revise a well-established concept in Brazilian literary historiography: regionalism. It tries to demonstrate that, in a certain way, there is no substantial difference between rural and urban fiction. This paper intends to prove that the main representation problem for regionalism, that being the distance between 
the urban literate narrator and rural illiterate characters, is also implicated when Brazilian fiction deals with marginalized urban characters.

Keywords: regionalism; Brazilian short story; Coelho Neto; Benjamim Costallat.

Recebido em 1 de maio de 2016.

Aprovado em 25 de julho de 2016.

Nossos barracos são castelos

Em nossa imaginação ${ }^{1}$

Numa passagem de "Recado do morro", de Guimarães Rosa, o protagonista Pedro Orósio, lavrador analfabeto, pensa sobre o grupo de letrados - um cientista, um padre e um proprietário de terras - que guia numa viagem ao Norte de Minas:

[...] Outros eram os outros, de bom trato que fossem: mas pessoas instruídas, gente de mando. E um que vive de seu trabalho braçal não cabe todo avontade junto com esses, por eles pago.

De qualidade também que, os que sabem ler e escrever, a modo que mesmo o trivial da ideia deles deve de ser muito diferente (ROSA, 1978, p. 10).

Pedro sente a distância que o separa daqueles homens e a define em termos de distância social, já que eles são os patrões e ele o empregado, "por eles pago". Essa separação, no entanto, é apenas a menos radical, já que uma segunda, irreconciliável, deixa-o alerta: o letramento. É que aqueles homens provavelmente pensam de maneira diferente da dele - são assim, criaturas muito apartadas, quase uma outra espécie. Não é à toa que, páginas adiante, ao se lembrar de contar a eles algo que, julga, iria interessá-los, acaba se calando, duvidando da possibilidade de comunicar-se integralmente com eles: "Embora, ficou calado. Expor tudo não era convinhável, ele não sabia fácil passar a ideia de como tinha sido, e eles podiam fazer maiores perguntas - cansava sua cabeça

${ }^{1}$ CAVAQUINHO, Nelson; QUEIROZ, Geraldo. Sempre Mangueira. 
distribuir a pessoas cidadãs um caso de tanto comprimento. Guardou consigo" (ROSA, 1978, p. 41).

$\mathrm{O}$ que queremos enfatizar aqui, menos do que a existência em si da separação entre o guia e os demais viajantes, é a sua radicalidade, que não se coloca, no entanto, nos termos daquela que tem servido à definição do regionalismo, ou seja, a velha oposição entre vida rural e vida urbana. Ao incluir em nossas preocupações uma separação que se inicia nas camadas mais profundas de cada indivíduo - no "trivial da ideia" - a sensação experimentada por Pedro Orósio ajuda a pensar o regionalismo de uma outra maneira.

Como sabemos, um dos problemas centrais da história do conto brasileiro da primeira metade do século XX repousa justamente na má fama da experiência dita regionalista, que foi abundante no período. Quem sintetizou esse julgamento negativo mais de uma vez foi Antonio Candido. Vejamos aqui duas dessas sínteses, afastadas mais de trinta anos uma da outra, um artigo de 1972 e uma entrevista de 2005:

Mas antes de ir além, um parêntese para dizer que hoje, tanto na crítica brasileira quanto na latino-americana, a palavra de ordem é "morte ao Regionalismo", quanto ao presente, e menosprezo pelo que foi, quanto ao passado. Esta atitude é criticamente boa se a tomarmos como um "basta!" à tirania do pitoresco, que vem a ser afinal de contas uma literatura de exportação e exotismo fácil. Mas é forçoso convir que, justamente porque a literatura desempenha funções na vida da sociedade, não depende apenas da opinião crítica que o Regionalismo exista ou deixe de existir. Ele existiu, existe e existirá enquanto houver condições como as do subdesenvolvimento, que forçam o escritor a focalizar como tema as culturas rústicas mais ou menos à margem da cultura urbana (CANDIDO, 2002, p. 86-87).

No tempo da Primeira República e do incremento da urbanização o regionalismo foi, ao contrário [do que se deu no tempo do Império], fator de afastamento e mesmo estranhamento entre ambos [o homem rural e o homem urbano], como se a intenção dos autores fosse marcar a diferença, acentuando o exotismo do homem rural e, assim, marcando a condição superior do homem urbano. Foi um 
processo de folclorização do regionalismo, visível na diferença entre o discurso civilizado do autor e o discurso rústico, quase caricatural dos personagens, excluídos de certo modo da norma culta. Era o tempo dos detestáveis "ocê tá bão?" e da redução reificadora do campesino a elemento pitoresco da paisagem. Penso em autores como o Coelho Neto de Sertão (CANDIDO, 2005, p. 33). ${ }^{2}$

Em ambos os trechos fica claro que o regionalismo - pelo menos o daquele momento - é visto como problemático, e suas insuficiências derivam de uma separação entre a experiência urbana e a experiência rural. O maior de seus problemas se localizaria na exploração do homem rural como algo pitoresco, despindo-o do que tem de humano e separando-o radicalmente do universo urbano do autor e do leitor dessas histórias. No primeiro fragmento há, além disso, uma sugestão fundamental, a de que essa separação se deva a condições sociais específicas expressas em termos caros aos anos de 1970, devidas ao subdesenvolvimento, vale dizer às enormes desigualdades de uma sociedade como a brasileira.

$\mathrm{O}$ que nos interessa aqui é refletir exatamente sobre as consequências estéticas dessa desigualdade, sobretudo em projetos literários de cunho realista como costumam ser os regionalistas. A pergunta central que fazemos é se essa desigualdade se reduziria a uma diferença entre vida rural e vida urbana. Para que isso fosse possível, seria necessário encontrarmos uma unidade na experiência urbana no Brasil (podemos dizer o mesmo a respeito da experiência rural) que está longe de se verificar na prática. Se identificamos a desigualdade como o traço definidor da sociedade brasileira, tudo o que se afirma exclusivamente sobre a literatura regionalista pode ser aplicacado a toda nossa experiência literária. E este é o ponto aqui, parafraseando Pedro Orósio: outros são os outros. Todos os outros.

$\mathrm{E}$, com isso, o regionalismo pode ser analisado como mais um caso do impasse de representação na narrativa brasileira, sem o peso negativo que de saída se lhe põe: como tratar ficcionalmente esse outro tão distante de mim que, seja vivendo no campo, seja morando na mesma

\footnotetext{
${ }^{2}$ Antonio Candido refere-se a esta entrevista, em carta incluída como apêndice à dissertação de mestrado de Marcelo Frizon Guadagnin (2007, p. 127), da seguinte maneira: "sobre regionalismo brasileiro, considero que a minha posiçã̃o está formulada de maneira que me satisfaz na entrevista com seu orientador Luís Augusto Fischer".
} 
cidade em que eu vivo, pela formação e pelas condições radicalmente diferentes das minhas, mesmo o trivial de suas ideias deve de ser tão diferente do meu?

Para defender uma abordagem que não separe o urbano e o rural a partir de uma marca que se assume como exclusiva deste último contexto, analisaremos dois contos, um de temática rural ou regional, "Banzo", de Coelho Neto, que integra o volume homônimo publicado pela primeira vez em 1913, e outro urbano, "A Favela que eu vi", de Benjamim Costallat, uma das histórias de Mistérios do Rio, saído em 1924. O objetivo é identificar até que ponto a "redução reificadora" de fato fica restrita ao regionalismo.

Antes de tratar de "Banzo", entretanto, é útil considerar alguns aspectos da obra de Coelho Neto, justamente o autor mencionado como exemplo negativo por Antonio Candido apenas no segundo trecho aqui citado, de 2005, mas que, embora ausente no fragmento transcrito do artigo de 1972, é, também naquele texto, o autor identificado como o que tipicamente praticou aquela redução reificadora dos personagens rurais. Candido considera especificamente um dos contos de Sertão (1896), "Mandoví", a partir do mesmo elemento destacado no segundo trecho, a distância entre a língua do narrador culto e a do personagem de origem rural, que tem todas as suas marcas de oralidade inscritas no texto, resultando numa espécie de caricatura. É assim que o personagem que dá título ao conto se expressa num trecho citado também por Candido (2002): “- Não vou? Ocê sabi? Pois mió. Dá cá mais uma derrubada aí modi u friu, genti. Um dos vaqueiros passou-lhe o copo e Mandovi bebeu com gosto, esticando a língua para lamber os bigodes. Té aminhã, genti” (COELHO NETO, [s.d.], p. 214).

O crítico faz um exercício curioso e bem conhecido, o de imaginar como ficaria o texto se o narrador, figurado como alguém culto do Rio de Janeiro, e o personagem "regional" recebessem o mesmo tratamento linguístico. O resultado é o seguinte: “- Não vô? ocê sabi? pois mió. Dácá mai zuma dirrubada aí módiu friu, genti. Un duch vaqueiruch passô lhocópo i Mandovi bebeu com gôchto, chticando a língua pra lambê ruch bigodich etc." (CANDIDO, 2002, p. 89).

Aliás, antes de prosseguir, vale a pena fazer um parêntese acerca dessa questão da transcrição ortográfica - já que fonética ela não é de uma certa variedade linguística em discurso direto num texto em que o status do narrador está garantido pela norma culta escrita, ou, 
dizendo de outra maneira, o uso daquilo que Antonio Candido chamou de "detestáveis 'ocê tá bão". A pergunta de base que devemos fazer é se o "ocê tá bão" é, por definição, detestável e sempre implica redução reificadora do personagem que o utiliza - e, por extensão, dos tipos humanos por ele representados. É sempre complicado estabelecer um valor apriorístico para um recurso literário, seja ele qual for. Para tomar como exemplo um autor valorizado por Antonio Candido, pensemos na pequena obra-prima do conto regionalista que é "O poço", de Mário de Andrade, incluído em Contos novos, em que o uso desse tipo de transcrição só faz assinalar a distância entre o mundo dos trabalhadores pobres e o do patrão, tão indiferente aos problemas desses homens. ${ }^{3} \mathrm{O}$ resultado é que os personagens pobres ganham em humanidade na medida em que o patrão os reifica diante dos olhos do leitor. Enfim, é útil não condenar automaticamente esse tipo de recurso sem antes verificar quais seus usos e efeitos em textos específicos.

De toda maneira, para além do dado linguístico ou estilístico explorado por Antonio Candido, a leitura de "Mandoví" mostra que outros elementos também marcam a distância entre o narrador e o personagem, o que inclui a configuração do enredo. Trata-se de uma narrativa que tem por tema a crença em manifestações do sobrenatural. Como Mandoví, o protagonista, no contraste com a visão do narrador numa espécie de camaradagem com seu irmão letrado, o leitor, é claramente caracterizado como uma espécie de irracional que, mesmo diante de provas claras de que o fantasma que ele vira na mata era apenas uma folha pendente numa palmeira, mexendo-se ao sabor do vento, ainda crê que viu um fantasma, aquela separação entre o mundo rural e o urbano se amplifica, de forma que, quando encerramos a leitura do conto, compreendemos perfeitamente a restrição que Antonio Candido faz a ele.

No entanto, em outros contos da mesma coletânea, o tratamento dado às distâncias linguísticas entre narrador urbano e personagens

\footnotetext{
${ }^{3}$ Notemos que em "O poço" o patrão diz consistentemente "você": "Não trouxe vocês aqui para fazer casa" (ANDRADE, 1983, p. 63); "Você acabou o remédio" (ANDRADE, 1983, p. 64); "Você me acompanhe" (ANDRADE, 1983, p. 65). Já os empregados da fazenda usam "ocê" ou mesmo "cê": "Ocê marcou, mano..." (ANDRADE, 1983, p. 63); "Então ocê vai ficar naquela dureza de trabalho com essa umidade!" (ANDRADE, 1983, p. 64); 9cê besta, mano! e sua doença!” (ANDRADE, 1983, p. 64).
} 
rurais é outro. Em "Cega", por exemplo, a linguagem pode ser descrita da mesma forma como, na entrevista citada acima, Antonio Candido caracteriza o regionalismo do tempo do Império, um "instrumento de revelação do Brasil aos brasileiros", quando se praticava "uma escrita ajustada à norma culta, com o mínimo indispensável de modismos regionais" (CANDIDO, 2005, p. 33). A mulata Ana Rosa dá à luz sua filhinha Felícia e fica cega. Este é o lamento que faz a seu marido, o caboclo Cabiúna:

- Ah! Meu caboclo... Aquela dor de cabeça, quando eu dizia a vocês que estava sentindo a modo de alguma coisa que me arrebentava por dentro. Eram meus olhos que estavam se apagando. Eram meus olhos, coitada de mim! E que há de ser agora? Juntou as mãos como em prece: Que há de ser de mim? (COELHO NETO, [s.d.], p. 147).

Nada de transcrição, nada de separação radical entre narrador e personagem. A única moda regional, aquele "a modo", aparece normatizado e com destaque, sem constituir exagero. $\mathrm{O}$ confronto desses dois exemplos nos diz que Coelho Neto de fato não havia encontrado um caminho para o impasse de representação desse outro. Parece mesmo que atende mais a uma solicitação diferente: o desejo de dar ao público o que ele eventualmente poderia querer. Num caso, reforça o cômico da superstição do caboclo ignorante, Mandoví, com a folclorização de sua fala. Noutro, trata com sobriedade o trágico da cegueira de Ana Rosa, aliás, como Mandoví, também envolta em superstições.

Na coletânea Banzo, publicada dezessete anos depois, o impasse ainda não está resolvido - ou, quem sabe, está resolvido, de maneira algo errática, naquele desejo de atender a expectativa do público. $\mathrm{O}$ fato é que em alguns contos, como "Traição", "Casadinha" e "No rancho" malgrado o caráter trágico deste último -, o discurso direto é próximo ao de "Mandoví", enquanto em contos como "Mau sangue" estamos diante de soluções mais próximas à de "Cega".

Nesse sentido, e chegando ao conto que nos interessa aqui, "Banzo" representa uma experiência diferente, um caso que nos faz pensar na necessidade de reavaliar o trabalho vasto e desigual de seu autor. Nele acompanhamos o final da vida de um ex-escravo, velhíssimo, o tio Sabino, que vive de lá para cá na região do Vale do Paraíba fluminense, 
“desde a Barra até o Paty" (COELHO NETO, 1927, p. 9).4 Marginal, vive da caridade alheia, seja porque pede esmolas nas estações de trem, seja porque é amplamente conhecido, seja porque tenha se tornado uma figura caricata, divertida:

Aparecia nas vilas e nas cidades em tempos de festa e, como conhecia todos os sítios e fazendas, ia entrando às porteiras como em terra própria, falando a todos, sempre risonho.

O urucungo anunciava-o; saíam crianças a recebê-lo, davam-lhe comida, molambos. O saco ia bojando e o negro, numa alegria servil, bambaleava o corpo em dança de urso, com gatimonhas ridículas, picando as aspas da cumbuca, grato à bondade das crianças que se ajuntavam em círculo, rindo, batendo as palmas (COELHO NETO, 1927, p. 9-10).

É assim que vive Sabino, sem pouso, dormindo ao relento, já que fora intempestivamente expulso da propriedade de que era propriedade antes da Abolição, pelo homem que, em criança, "ele carregara à 'cacunda', ensinara a andar a cavalo, levara ao colégio, vira casar, envelhecendo no trabalho, à sombra da casa" (COELHO NETO, 1927, p. 10-11): 'Um dia, já depois da Lei, 'Nhô Roberto', que andava nervoso, entrou na horta e achou-o sentado perto do rego, chupando uma laranja. Foi um tempo quente, não quis saber de desculpa - pô-lo fora. 'Que fosse para o inferno! Estava livre, os canalhas que o sustentassem"' (COELHO NETO, 1927, p. 11).

Logo na apresentação do personagem, portanto, fica claro que se trata de um deslocado, de uma espécie de resquício do passado, lançado à rua em plena velhice exatamente no momento em que poderia desfrutar da liberdade garantida pela lei. Como é velho, testemunhou todas as transformações por que passara a região, vendo em tudo perda: a derrubada das matas, a extinção das fontes, o enfraquecimento das águas do rio Paraíba, as transformações nas vilas e nas fazendas, os bichos que minguavam nas matas, os pés de fruta antes disponíveis e agora cercados pelos proprietários.

\footnotetext{
${ }^{4}$ O narrador refere-se aos municípios de Barra do Piraí e Paty do Alferes, no interior do Rio de Janeiro, distantes aproximadamente cinquenta quilômetros um do outro, em linha reta.
} 
E os ex-escravos, o que se fizera deles? Temos boa pista disso na resposta que tio Sabino dá quando lhe perguntam sobre o tempo da guerra do Paraguai:

Eh! mato comeu gente! Eu estive vai, não vai... Barnabé ficou lá, Brás ficou lá, um bandão deles. Desse tempo só Venâncio mina, coitado! Está no Quatis, cego de todo. Não sabe nada, pergunta só. Lei grande já apanhou ele sem vista, para quê? Tinha senhor, vivia na fazenda... e agora? Está morrendo no escuro, come hoje, amanhã não come, conforme Deus quer. Liberdade... pois sim! Gente anda morrendo à toa, urubu é que gosta (COELHO NETO, 1927, p. 18).

Num trecho como este é possível apontar os elementos gerais de composição do conto. No plano da linguagem, o narrador supera aquela dicotomia entre língua culta do narrador e língua estereotipada do personagem por meio de um recurso que, em termos bastante amplos, seria o utilizado por Graciliano Ramos em Vidas secas: o discurso indireto livre. Em nenhum momento o tio Sabino se nos apresenta em discurso direto. Isso não quer dizer que não se faça qualquer diferença entre narrador e personagem. É possível observar, no fragmento acima, que várias marcas de oralidade se mantêm, como o uso constante de interjeições, as frequentes perguntas retóricas e mesmo detalhes significativos como o emprego do pronome reto em posição de objeto em "apanhou ele". Nenhuma delas, no entanto, produz excessivo contraste com o discurso indireto do narrador, mesmo que a narrativa ainda tenda, em certa medida, como era típico de Coelho Neto, a deixar-se "dominar pela palavra, em lugar de dominá-la" (PEREIRA, 1957, p. 261). Ainda assim, em "Banzo", até mesmo nas descrições, em que o escritor costumava espraiar-se e deixar-se levar por uma certa volúpia verbal, há a preocupação de não abandonar o personagem principal, de não deixar desfalecer a tensão que a narrativa lentamente constrói.

No que diz respeito ao enredo e à caracterização do protagonista, vemos que ambos se desenvolvem naturalmente, a partir das impressões e dos sentimentos do ex-escravo acerca do mundo que vê no presente, sempre contraposto ao que ele conhecera no passado. E, não podemos esquecer, ele é um velho que mistura, em suas impressões, a observação, digamos, objetiva da transformação predatória promovida pela 
modernização na região com o apego ao mundo que conhecera na juventude, anterior à chegada do trem - basta dizer que, para ele, o "próprio céu descorado esmaecia, cada vez mais pálido" (COELHO NETO, 1927, p. 20).

Não é à toa que ele terá ódio dos colonos brancos que agora se ocupam das tarefas que antes eram executadas pelos escravos. Vai considerá-los usurpadores: "Não, a terra era deles que a desbravaram e plantaram para os senhores" (COELHO NETO, 1927, p. 25). Não podemos dizer que se trata de sentimento sem razão. É, todavia, um ódio calmo o que ele sente, sem aspirar ao conflito: "Se avistava algum [colono branco] na estrada, desviava-se, deixava-o passar e voltava-se com o olhar até perdê-lo de vista" (COELHO NETO, 1927, p. 25).

A esta altura, já é possível considerarmos a que se refere o título do conto, "Banzo".

Cativeiro era brabo, isso... ahn! Mas também, quando o senhor ganhava, negro tinha o seu gancho. Tempo bom! E, descrevendo, dramatizava pitorescamente os episódios imitando: a música: tchumba! tchumba! tchumba! o espocar dos foguetes e o estrondar dos morteiros: tró tó ró bum! o bimbalhar dos sinos: bem, de len den bem, bom! O rebuliço dos carros rinchando: cheeeem... hiiiim... os cavalos resfolegando: rru! o rumorejo do povo: áaaah! os pregões dos doceiros, dos leiloeiros de prendas, o batuque africano ao som dos tambores: pru cu tu! pru cu tu! (COELHO NETO, 1927, p. 14)

O cativeiro, na visão de tio Sabino, "era brabo" e era bom ao mesmo tempo. E essa verdadeira confusão advém, é verdade, em parte, desse olhar de velho que tem a tendência de recusar o presente e prenderse ao passado, sempre idealizado. Mas advém também de que naqueles tempos, os do passado, tio Sabino pertencia a uma ordem qualquer, mesmo que na pior posição. Agora, tudo lhe foge, nada lhe pertence e ele não tem lugar.

Enfim, é forçoso perceber que, nesta narrativa, a palavra "banzo" muda radicalmente de sentido, deixando de se referir ao sentimento de perda da terra-mãe e se convertendo em dolorosa saudade da própria escravidão. Nada fica simplificado aqui: nos vemos diante de um curtocircuito verbal. 
Se há algum elemento com que podemos implicar no conto, este é o desfecho sentimental, produzido mais ou menos como num outro texto do volume, muito menos bem construído do que "Banzo", o trágico "Atração pela terra" - em que assistimos à morte de uma menina de oito anos, filha de faroleiro, que cresceu numa ilhota e se sente atraída pelo continente - cujas ações se desenvolvem perceptivelmente com vistas apenas a atingir o final trágico - um corpo boiando em vaivém, nem deixando a ilha nem voltando a ela - e não por motivações engendradas pelo enredo ou pela psicologia da personagem. Já em "Banzo", ao saber que derrubaram uma enorme gameleira que lhe era particularmente cara, $o$ tio Sabino, noite fechada, vai até a fazenda em que ela jaz e simplesmente aparece morto no dia seguinte. O final explicitamente tocante pode ser visto como desnecessário num conto que já deu tanto ao leitor, inclusive a incômoda sensação de que alguém vivendo um presente tão sem sentido pode sentir falta da pior das condições, a escravidão. Mas não anula a força do relato, a construção de uma figura forte que se refere a um processo histórico traumático. Haverá outra narrativa contemporânea a ela - lembremos que a escravidão havia acabado apenas 25 anos antes - que desenhe o período que segue à Abolição de forma tão crua como "Banzo" o faz?

De toda maneira, estamos diante de algo muito diferente da folclorização desse homem que é do campo e é escravo, distante quilômetros do homem urbano que se constituirá em leitor de sua história. Dessa forma, mesmo no interior da obra que a crítica - e é bom lembrar que esse julgamento não é uma idiossincrasia de Antonio Candido assinala como tipicamente exploradora do que haveria de pitoresco nas vidas de regiões afastadas dos grandes centros, é possível localizar momentos significativos para a tradição literária brasileira. Mesmo numa tendência tão desvalorizada, à partida, como é a regionalista.

Ora, isso nos leva a perguntar, afinal de contas, o que poderíamos encontrar na literatura urbana do início do século, quando o Rio era a única grande metrópole brasileira, se pensarmos que as distâncias sociais não coincidem necessariamente com as distâncias entre o campo e a cidade. Será que a representação do homem urbano pobre não poderia ter passado pelas mesmas dificuldades que costumamos localizar na do homem rural?

Benjamim Costallat foi um dos mais populares cronistas dessa metrópole. Em 1924 foi contratado pelo Jornal do Brasil para produzir 
uma espécie de raio-x alternativo da capital federal sob o título de Mistérios do Rio. Em entrevista publicada na véspera do início da publicação do projeto no jornal, o autor enfatiza dois de seus aspectos. Um é o de que as narrativas são verdadeiras, ainda que com um tempero de fantasia: "Apenas olhei e narrei. A composição literária, às vezes, exige uma certaxaxp fantasia. Mas peço ao público que acredite [...]" (COSTALLAT, 1924, p. 7). O outro é que, até por sua obsessão com a verdade, os Mistérios do Rio nada teriam que ver com Os mistérios de Paris, pois ele considerava o folhetim "um gênero literário [...] inferior e cujo maior mérito é mentir desbragadamente" (COSTALLAT, 1924, p. 7):

- Os Mistérios, não sendo romance-folhetim, são crônicas, são contos, são reportagens?

- Tudo ao mesmo tempo, ou ora uma coisa, ora outra, conforme o tema, mas sempre numa absoluta base de verdade (COSTALLAT, 1924, p. 7).

Reunidos em livro no mesmo ano, os Mistérios do Rio podem ser vistos, apesar da indefinição que seu autor prefere alimentar, como uma série de contos, ainda que o caráter de reportagem, mãe da tal verdade por ele sempre mirada, de fato procure contaminar todo o volume. Para encurtar essa discussão acerca das aproximações possíveis entre os mistérios de Costallat e os de Eugène Sue, vejamos como Júlia O’Donnel (2012, p. 126-127) as sintetiza:

Apesar da insistência no mote da veracidade de seus relatos, o nome e o perfil da série não passam despercebidos. Ainda que Costallat negasse a relação, seus Mistérios do Rio lembravam em muito Os mistérios de Paris, popular romance de folhetim de Eugène Sue, publicado pelo Journal des Débats entre 1842 e 1843, e cujo enredo se desdobra entre crimes e contravenções, revelando uma faceta pouco conhecida da capital francesa. Mais que uma discussão acerca da veracidade dos relatos narrados pelo autor, tal referência suscita uma reflexão acerca da inserção de sua série numa tradição pautada pela ficcionalidade. Permeadas de suspense, as narrativas que Costallat oferecia aos seus leitores eram pródigas em aventuras, explicitando um trânsito bastante fluido entre realidade social e prosa ficcional. 
É importante acrescentar, além de seu caráter ficcional mas realista e de sua intenção de revelar o submundo da cidade, um outro aspecto dos Mistérios de Paris que aqui e ali também ronda esses Mistérios do Rio, exatamente aquele a que Umberto Eco (2011) dedica grande atenção: o impulso de denúncia social. Tal impulso se faz presente logo no primeiro texto publicado pelo Jornal do Brasil (oitavo na publicação em livro), no dia 1 - de maio de 1924. Como se tratava do Dia do Trabalho, escolheu-se para dar início à série "A pequena operária", a história trágica de Helena, uma costureira que morre doente e abandonada por uma "organização social errada e bandida" (COSTALLAT, 1990, p. 66). Curiosamente, esta é uma das poucas em que não surge aquele narrador-repórter que vai visitar um lugar verdadeiro para descrevê-lo ao leitor ávido por conhecer aquilo que, em sua cidade, é exótico. É antes um morador da cidade que se apieda do horrível destino da moça que, por não querer entregar seu corpo por interesse, acaba morrendo à míngua. Trata-se mesmo do texto em que a denúncia social, ainda que expressa em termos bastante gerais - e sentimentais -, tem maior relevo em toda a série.

O segundo texto a ser publicado, no dia 4 de maio, foi exatamente aquele que interessará mais de perto aqui, "A Favela que eu vi". Nele a intenção de denúncia social desaparece, e aquele narrador-repórter interessado em revelar a verdade está presente - assim como estará presente noutros textos, nos lugares onde se vende cocaína, nas casas de jogo, nos prostíbulos caros, nas instituições que, disfarçadas de sanatórios, procuram livrar da dependência química os filhos da elite. Acontece que o repórter é alguém de fora, cujo olhar pode ser comparado ao do turista no sentido em que Lúcia Miguel Pereira (1957, p. 180) utiliza o termo em relação ao escritor regionalista: "Há em sua atitude alguma coisa da do turista ansioso por descobrir os encantos peculiares de cada lugar que visita, sempre pronto a extasiar-se ante as novidades e a exagerar-lhes o alcance". Tal definição, aliás, parece feita sob medida para o narrador de "A Favela que eu vi", já que este está ansioso para revelar ao seu leitor algo que é novo, tanto para um como para o outro, extasiando-se com frequência, mesmo que seja com algo que considere escabroso.

E o que ele narra é uma visita, em companhia de alguém não nomeado, ao famoso Morro da Favela, no centro do Rio. Nessa visita, partilhará com o leitor sua estranheza e seu medo. A visita começa pela rua que dá acesso ao morro: "Descemos na rua da América. Uma das ruas 
mais sórdidas do Rio de Janeiro. Enlameada, imunda" (COSTALLAT, 1990, p. 33). Logo em seguida vem uma ponte:

Ligada ao morro do Pinto pela Ponte dos Amores, a Favela, com os seus casebres, rebrilhava ao sol.

Ponte dos Amores!...

Ela bem podia se chamar Ponte dos Suspiros, como a sua colega de Veneza.

Apesar de não ser de mármore, como a ponte do doges, e sim de madeira muito tosca, a ponte que liga o Pinto à Favela tem visto também suspirar muita gente. Tem visto muito suspiro de agonia... (COSTALLAT, 1990, p. 33).

Ainda antes de chegar ao morro, o que temos diante de nós é o que há de mais sórdido, logo seguido pelo que há de mais perigoso, nessa ponte onde tanta gente é assassinada - ainda que o narrador nos avise de que mais recentemente há mais roubos que mortes ali. Essa ponte separa o morro do Rio de Janeiro, cidade a que pertence, mas a comparação com Veneza, tão fora de propósito, exceto se o propósito for criar o exótico e o ridículo, acaba separando-a do mundo civilizado.

De toda forma, é sempre com medo, como se entrasse num mundo fora do mundo, que o narrador nos apresentará o lugar. Primeiramente seremos informados das ruas onde vivem os bandidos de diferentes especializações: ladrões, receptadores, assassinos. Em seguida, o espaço físico, a subida difícil, o perigo que corre quem anda pelo morro de despencar lá de cima. A partir daí finalmente a paisagem humana começa a surgir. E ainda antes que qualquer figura se destaque - na verdade dois dos moradores conversarão mais longamente com esse narrador-repórter - o que introduz a população do morro é um sentimento compensatório, a velha lição de vida que aqueles que não são marginalizados deveriam tirar da vida dos pobres:

Deus protege a Favela!...

E a Favela merece a proteção divina porque ela é alegre na sua miséria.

Aquela gente, que não tem nada, dá uma profunda lição de alegria àqueles que têm tudo.

Sem higiene, sem conforto, naqueles pequeninos casebres fétidos e imundos, que se arriscam, a cada instante, a voar com o vento ou despencar-se lá de cima; aquela 
população de homens valentes - estivadores, carvoeiros, embarcadiços - e de mulheres anemiadas e fracas, e de crianças mal alimentadas e em trapos, cria porcos, bebe cachaça, toca cavaquinho e canta!...

$[\ldots]$

Apesar da miséria em que vive, toda a Favela, sambando, é feliz sob um céu salpicado e lindo de estrelas!... (COSTALLAT, 1990, p. 34-35).

Está aí inteira, como vemos, a postura do turista. Apenas que, em vez de se encantar com a simplicidade da vida no campo, encantase com a alegria do pobre no morro. E essa postura se mantém quando, para além do espaço, o texto tratar de pessoas. São duas, como adiant, as personagens que se individualizam no conto. A primeira delas é uma mulher em princípio não identificada, a quem os visitantes abordam perguntando se há cinema no morro. É claro que não há, mas também seria desnecessário. Afinal, noutro dia mesmo alguém tocara fogo ao próprio corpo. E todos os dias, segundo essa moradora-informante, haveria um espetáculo qualquer para ser apreciado ali: "Mulheres nuas, tiros, facadas, paus-d'água" (COSTALLAT, 1990, p. 36). Como bom turista, no entanto, o narrador é curioso e lança a pergunta: "A vida aqui é boa?" (COSTALLAT, 1990, p. 36). A resposta é direta:

- É, vivo com o meu homem que trabalha no carvão dos "navio". É português, mas chega preto em casa.

- O homem é ciumento?

- "Terrive"... Não me deixa nunca ir lá embaixo sem ele... Qualquer coisa que "percise": fósforos, feijão, arroz, ele mesmo é que traz! Qualquer desconfiança que tenha, lá vem bordoada (COSTALLAT, 1990, p. 36).

Mais do que a representação da linguagem da personagem, que não é exagerada como a de "Mandoví", mas mantém marcas de oralidade devidamente assinaladas entre aspas, o que salta à vista aqui é exatamente aquilo que tanto incomodara Antonio Candido no regionalismo brasileiro da Primeira República: o pitoresco, que se concretiza em mais uma estranha forma da felicidade, a derivada de uma vida compassada pelo controle e pela pancada. A vida de dona de casa, que além dos afazeres cotidianos ainda se dedica ao bordado - "tosco, de letras tortas, mas com ortografia” (COSTALLAT, 1990, p. 36) -, ficamos sabendo, representa 
o fim de uma vida dedicada à "bagunça", que deixou marcas - "nomes de homens em horríveis tatuagens, talhos cicatrizados de navalha" (COSTALLAT, 1990, p. 36) - no corpo daquela que fora figura conhecida da cidade, a "ex-Taís da Saúde" (COSTALLAT, 1990, p. 36), vinda dos bordéis que são tema de uma outra narrativa do volume, "Quando os cabarets se abrem". Com a identificação dessa moradora anônima, que descobrimos ter sido figura célebre da "bagunça", como a caracteriza o narrador, o que temos diante de nós é o mundo exótico dentro - ou para além - do próprio mundo exótico.

O mesmo se dará com o outro personagem que acompanhamos mais de perto, o Zé da Barra. Com ele estamos noutro lugar, já que se trata do manda-chuva do morro, o "presidente da pequena república da Favela" (COSTALLAT, 1990, p. 37-38), cujas origens regionais, curiosamente, são as mesmas de tio Sabino de Coelho Neto - aquele "da Barra" referindo-se também à Barra do Piraí. É claro que o poder desse homem foi conquistado e se mantém pela violência - o cacete com que golpeia os inimigos é famoso. No entanto, temos diante de nós uma figura bonachona, um boa-praça que possui a melhor venda da Favela e recebe gentilmente os visitantes. Ali conta suas aventuras e trata de outros valentes que viveram na Favela, num bate-papo agradável à mesa: "Almoçamos com Zé da Barra. E nunca comi uma galinha tão gostosa!" (COSTALLAT, 1990, p. 38). Curiosamente, aqui não há, como no caso da personagem feminina, transcrições ortográficas nem aspas no discurso direto de Zé da Barra, que fala um português semelhante ao do narrador, por vezes até mesmo com cuidados visíveis com a colocação pronominal:

- Cheguei da Barra do Piraí ainda moço. Mas já trazia o meu prestígio. Aqui na Favela tenho lutado muito, mas tenho sido, graças a Deus, feliz! Várias emboscadas têm me sido armadas. Mas tenho me saído bem de todas elas. A última vez escapei por milagre. Ia subindo o morro, tarde da noite, quando atrás das pedras alvejaram-me a tiros. Eu não via quem estava atirando, só percebia a direção de onde partiam as balas... (COSTALLAT, 1990, p. 38)

Depois de uma tarde toda passada com o chefe do morro, ouvindo os relatos que dão conta de uma violência amena, quase heroica, o narrador e seu acompanhante seguem até um último ponto do morro, o Buraco Quente, onde tempos antes o outrora grande valentão Sete Coroas 
fora morto e é agora liricamente ocupado por meninos empinando pipas ao pôr do sol. Ao final do dia, temerosos da noite que se aproxima, mas a salvo de todos os sustos, podem voltar desse lugar peculiar, sãos e salvos, para a grande metrópole:

Com muito custo descemos, chegamos, finalmente, à rua, ao pé do morro. Voltávamos à vida, à cidade, com luz, com ruas, com bondes.

A Favela, no escuro, só possuía, de quando em quando, a iluminação de seus pobres lampiões de querosene (COSTALLAT, 1990, p. 39).

E voltar à metrópole é voltar à vida, como se aquilo que na Favela houvesse fosse uma coisa qualquer que não a vida sendo vivida - apesar das idealizações que tendem a ver nos barracos castelos onde impera a felicidade, uma felicidade que, garante o narrador, não somos capazes de apreciar vivendo uma vida de verdade. Mais do que revelar o outro, o que o texto de Benjamim Costallat faz é revelar o que vai no trivial da ideia de uma parcela da parte letrada do Brasil, aquela capaz de se colocar sempre a uma distância segura mesmo daqueles que estão ali do lado, depois da ponte.

No arco que vai do ex-escravo de fazenda sem lugar ao não lugar dos habitantes da Favela carioca, o que a literatura brasileira, regional ou não, tem feito é lidar com uma situação de desigualdade que, a despeito da rápida urbanização que o país viveu nas últimas décadas, ainda está longe de ser extinta e que, portanto, continua trazendo problemas sérios de representação. Afastar os pólos rural e urbano dessa desigualdade, escolhendo a literatura regional como o espaço da restrição de visão, da constituição de um pitoresco, é simplificar o problema e reduzir a amplitude daquilo que a tradição literária brasileira foi capaz de produzir. Barra do Piraí - como o sertão - ainda está em toda parte.

\section{Referências}

ANDRADE, Mário de. O poço. In: . Contos novos. 11. ed. Belo Horizonte: Itatiaia, 1983.

CANDIDO, Antonio. A literatura e a formação do homem. In: Textos de intervenção. Organização de Vinicius Dantas. São Paulo: 34, 2002. p. 77-92. 
CANDIDO, Antonio. Antonio Candido: um olhar decisivo sobre o Brasil. Entrevista concedida a Luís Augusto Fischer. Arquipélago - Revista de Livros e Ideias, Porto Alegre, n. 1, p. 28-34, mar. 2005.

COELHO NETO. Banzo. 2. ed. Porto: Lello, 1927.

COELHO NETO. Sertão. 6. ed. Porto: Lello, [1s.d.].

COSTALLAT, Benjamim. Benjamim Costallat inicia amanhã no Jornal do Brasil os seus Mistérios do Rio. Entrevista. Jornal do Brasil, Rio de Janeiro, p. 7, 30 abr. 1924.

COSTALlAT, Benjamim. Mistérios do Rio. Rio de Janeiro: Secretaria Municipal de Cultura, 1990.

ECO, Umberto. Eugène Sue, Je suis socialiste. In: SUE, Eugène. I misteri di Parigi. Milano: BUR, 2011. p. 5-27.

GUADAGNIN, Marcelo Frizon. O regionalismo na literatura brasileira: o diagnóstico de Antonio Candido. 2007. 127 f. Dissertação (Mestrado em Literatura Brasileira) - Instituto de Letras, Universidade Federal do Rio Grande do Sul, Porto Alegre, 2007. Disponível em: $<$ https://www.lume. ufrgs.br/bitstream/handle/10183/10794/000601404.pdf?sequence=1 $>$. Acesso em: abr. 2016.

O’DONNEL, Júlia. A cidade branca - Benjamim Costallat e o Rio de Janeiro dos anos 1920. História Social, Campinas, n. 22-23, p. 117-141, 2012.

PEREIRA, Lúcia Miguel. Prosa de ficção (de 1870 a 1930). 2. ed. Rio de Janeiro: José Olympio, 1957.

ROSA, Guimarães. Recado do morro. In: . No Urubuquaquá, no Pinhém. 6. ed. Rio de Janeiro: José Olympio, 1978. p. 5-70. 